\title{
John Sears
}

\section{George Szirtes's Meetings with "Austerlitz"*}

This essay addresses two recent long poems by Hungarian-born English poet George Szirtes ("Backwaters: Norfolk Fields" and "Meeting Austerlitz") to analyse their constructions of the literary friendship between Szirtes and his fellow writer, German-born W. G. Sebald. The poems are read through critical approaches informed by Blanchot, Derrida, and others, and through their connections with key precursor texts, to examine the complex interconnections they explore between themes of history and tradition, geography and place, text and canon and self and other. The essay argues that the two poems engage with a series of figures that ultimately offer literature itself as a shared space in which each writer finds a territory to substitute for that of home, while yet residing in a condition of exotic, displaced migrancy; the poems focus on language, writing and specific aspects of the English literary tradition in order to establish these spaces as grounds for a shared experience that transcends the irreducible singularity of the specific histories which each writer has, in radically different ways, encountered.

\author{
They are \\ migrating souls who've travelled far \\ to get to places such as these. . .
}

(George Szirtes, Sisyphus).

George Szirtes was born in Budapest in 1948. His family fled from Hungary in the 1956 uprising, first over the border into Austria, then to London. As an adult he has lived and worked as a poet, artist and teacher in the south-east of England, in Hitchin and most recently in East Anglia. He has published several collections of poetry since 1979, and is also an accomplished translator, editor and essayist. In a sonnet sequence published in 1999 entitled "Backwaters: Norfolk Fields" ${ }^{1}$ Szirtes

\footnotetext{
* Portions of this paper were presented at conferences at the University of Debrecen (September 2004) and the University of Warwick (February 2005).

1. All parenthesised references are to this edition: George Szirtes, "Backwaters: Norfolk Fields," in An English Apocalypse (Tarset: Bloodaxe Books, 2001), 103-8.
}

The AnaChronisT 11 (2005): 321-340 ISSN 1219-2589 
addresses the themes of landscape, belonging, language and shared experience in order to assert significant connections between his own writing and the narratives, poems and critical essays of the writer W. G. Sebald, to whom this poem is dedicated. Like Szirtes, Sebald was a writer-in-exile; he was born in Bavaria and, like Szirtes, lived and worked as a university lecturer in East Anglia. Sebald was killed in a car crash in 2001. Szirtes's later long poem "Meeting Austerlitz,"2 first published in 2002, extends his engagement with Sebald by offering an extended meditation on Sebald's death.

Both written in the last six years, these two major poems explore themes and concerns connected to the relationship between the two writers, which are grounded in the symbolic potential of melancholy as an emotional response to historical consciousness. Sebald's rendering of melancholia as a theme is well known and permeates his writing; Long and Whitehead note that he "is often described as a melancholic writer." 3 Szirtes has recently commented on "the notion of loss" which, he argues, is "firmly embedded in the Hungarian literary imagination." "The very word melancholy," he continues,

the one-syllable word bú (pronounced like a long 'boo'), and its adjective bús (booosh) recur time and again in Romantic and early twentieth-century poetry, partly as pose and garb (you can never make that 'oo' sound quite long or closed enough) but partly as a sound in the very depths of the chest and the spirit. 4

The personal causes of such melancholy, and reasons for its re-emergence as a significant emotional tone in the contemporary English poetry he writes, are central subjects of Szirtes's oeuvre. Its relations to individual and collective historical experiences of dislocation, exile and loss and its literary expression in relation to personal and public memory arguably constitute major dimensions of the concerns of both Szirtes and Sebald.

The two Szirtes poems addressed here analyse encounters with a fellow writer that initiate, even demand, a series of meditations on history, empire, exile and be-

2. All parenthesised references are to this edition: George Szirtes, "Meeting Austerlitz," in Reel (Tarset: Bloodaxe Books, 2004), 17-24.

3. "Introduction" to J. J. Long and Anne Whitehead eds., W. G. Sebald: A Critical Companion (Edinburgh: Edinburgh University Press, 2004), 3-15, p. 9.

4. George Szirtes, "Introduction" to Leopard V - An Island of Sound: Hungarian Poetry and Fiction before and beyond the Iron Curtain, ed. George Szirtes and Miklos Vajda (London: The Harvill Press, 2004), xiv-xxxiv, p. xvi. 
longing and the functions of place and poetry in relation to them. Language is put to work to construct a particular kind of intimacy between the two writers, predicated on an acknowledgement of the irresolvable exteriority of the experience of the other in relation to the self's attempts to comprehend it. What begins, in "Backwaters: Norfolk Fields" as something akin to what Maurice Blanchot means by "the intimacy of exteriority" 5 develops, in "Meeting Austerlitz," into a profound awareness of the relations between such exterior intimacy and the fact of dying, which is, in the later poem, embedded in the (belated, posthumous) effort to represent and recuperate in literature the experience of or encounter with the other, which becomes a symbolic guarantor of the efficacy of the subject constructed in poetry and memory. Intimacy is, in Szirtes's renderings of his encounters with Sebald, the potential to share the experience of exclusion, the encounter with the exotic as shared exclusion, and the experiences of the located self as excluded from itself and from the histories and geographies in which it seeks its own location.

Both poems offer an extended and detailed analysis of the ways in which writing affords, in its discursive rendering of such displaced and displacing encounters, a particular kind of space in which elective and other affinities can develop. Such a space of writing accommodates not only the shared experiences of each writer, but also the individual otherness that each encounters, and the deeper historical consciousness that Szirtes's poems seek to evoke as a common template from which each writer's work develops. This historical consciousness includes a history alien to the specifically English, East Anglian territories mapped out in each poem; European histories, implicit in each poem and integral to an understanding of both Szirtes and Sebald, exist as residual allusions (to Polish Conrad, to Dutch Rubens) and are implied as horizons of (im)possibility, against which the detail of contemporary observation receives a different kind of scale for its measurement, a scale that seeks to incorporate "the writing of the disaster" 6 of modern Europe, a disaster signified in images of decline, decay, ending and destruction, images common to the writings of Szirtes and Sebald.7 Each poem constructs the landscape and the historical context in which it situates itself in order to locate and temporise its own analysis and to

5. Maurice Blanchot, The Writing of the Disaster, trans. Ann Smock (Lincoln and London: University of Nebraska Press, 1995), p. 54.

6. Blanchot, The Writing of the Disaster, passim.

7. Sebald's pre-occupations with such concerns are discussed in several essays in W. G. Sebald: A Critical Companion, including Greg Bond, "On the Misery of Nature and the Nature of Misery: W. G. Sebald's Landscapes," 31-44; and John Beck, "Reading Room: Erosion and Sedimentation in Sebald's Suffolk," 75-88. 
depict the central encounter against the backdrop of the history embodied in and yet, at its extremes, exotic to that landscape. In each case, landscape acts as figure for the experience of geographical and historical displacement - a figure, ultimately, for absence - which in turn becomes reified in an assertion of the space of literature as habitable territory, in which each writer can find and enter into new, productive relations to the self, to the other and to literary traditions.

\section{"Backwaters: Norfolk Fields"}

"Backwaters: Norfolk Fields" (1999) establishes many themes and concerns developed in the later "Meeting Austerlitz." The earlier poem is a twelve-sonnet sequence (such sequences, with many variations in length and form, are common in Szirtes's oeuvre $^{8}$ ) published in An English Apocalypse and prefaced with the dedication "For W. G. Sebald." The poem is included in a sequence of new poems in a collection the function of which is to anthologise Szirtes's poems about his English experience, narrating in their totality an 'outsider's view' (or "temperature chart," in Szirtes's own words 9 ) of "a spectral country living out its past," as the cover blurb puts it. "Backwaters: Norfolk Fields" is a long poem of extraordinary subtlety and complexity that offers a vision of this "spectral country," and, in doing so, seeks to confirm, in its analysis of (English) history and (European) exile, the intrinsic connections between Szirtes's poetry and Sebald's oeuvre.

In this poem Szirtes meditates upon a shared environment in order to initiate a coded dialogue between his own work and that of Sebald, just as "Meeting Austerlitz" later seeks a different dialogue, or rather to extend the dialogue into a different set of relations. From the opening line's sequence of paired words - "Backwaters. Long grass. Slow Speech. Far off" - Szirtes establishes territory, disuse, language and distance as the fundamentally interconnected parameters of his exploration of the landscapes and histories of place that constitute the "Norfolk Fields," an environment encountered by both Sebald and Szirtes in radically different but formally analogous circumstances, and ultimately experienced by both, despite the poem's initial use of the inclusive "We," from the point of view of the "outsider":

We're years behind. Even our vowels sag

in the cold wind. We have our beauty spots

8. Compare, for example, from recent collections, "The boys who beat up my brother" in Szirtes, An English Apocalypse, 70-2; and "Black Sea Sonnets" in Szirtes, Reel, 90-94.

9. Szirtes, "Preface," An English Apocalypse, p. 12. 
that people visit and leave alone, down main arterials and side roads. A paper bag floats along the beach. Clouds drift in clots of grey and eventually down comes the rain. (Sonnet 1, 103)

Here the assertion of historical persistence (echoing in its tone the rhetorical flourishes and broad historical sweep of another contemporary elegy to East Anglia, Graham Swift's Waterland) breaks down into a shared present of isolated images; "sagging" vowels decline into silent, disconnected images of desolation, and solitude and isolation (the word "alone" seemingly central to the passage) initially overwhelm the traces of a social world already implicitly sick ("spots" and "clots" rhyming external and internal signs of malaise). "We're at the end," the poem continues contradictorily - not behind, but too far advanced, beyond even decline: "It might simply be of weather / or empire or of something else altogether." While the final clause establishes an initially indeterminate but radical otherness as central to the poem's analysis, this deliberately unspecific historical diagnosis rests uncomfortably with the poem's construction of a detailed and highly imagistic visual rhetoric through which to encode the emotional resonances embedded within a specific landscape. Such tension, between the deliberately vague and the meticulously specific, typifies Szirtes's poetry, in which the reliably visual (Szirtes is an artist as well as a poet) frequently overrides perceptual and interpretative uncertainties to provide at least some sureness, the quality of specular precision of the artist offering something to rely upon in a contemporary world of fundamental uncertainty. "Backwaters: Norfolk Fields" hovers within this tension, exploiting it to generate its initial sensation of frustrated stasis, of teetering on the brink of an impending "English Apocalypse."

The second sonnet switches from "We" and "I" to "You," the indeterminate second person address frequently used by Szirtes to account for self, narrator and reader as compound, ambiguous addressees involved a new level of uncertain complicity. "You cannot wipe the face / of the clock or restore a vanished kingdom," we are warned; historical processes are irreversible, the poem argues, as the emptiness of the landscape begins to take on allegorical significance, much as it does in Sebald's The Rings of Saturn, his own travelogue of a walk around Suffolk (the county bordering Norfolk), with its opening descriptions of the "thinly populated countryside" and "the traces of destruction" "that were evident even in that remote place."10 Szirtes notes the seeming significance of natural forces in "The wind at its eternal

10. W. G. Sebald, The Rings of Saturn, trans. Michael Hulse (London: The Harvill Press, 1998), p. 3. 
droning harangue"; nature itself is an active contributor to the social desolation, "the empty houses" in "the back of beyond" (Sonnet 3, 104).

Natural and social desolation are, the poem suggests, comparable figures of historical abandonment, and summarise the poem's representation of the experience of dislocation to the margins (the end) of time and space, exclusion from the centres of agency to the ends of the earth (a rhetorical implication developed intertextually in the poem's later allusion, in Sonnet 7, to Conrad's Heart of Darkness). With this allegorical import established, the poem turns towards the social in order to extend it further and to ground it in contemporary observation. Figures in the landscape reply to the construction of landscape as figure by assuming parabolic significance (the man in the third sonnet is "biblical"; social roles metonymically replace people in Sonnet 4, allowing the poem's meditative shift towards the significance of naming as the determining function of identity). Again, recorded visual detail provides a shorthand for the underlying themes; "War memorials" appear suddenly amid the names, bearers of names themselves as well as markers of the traces of history towards which the poem ceaselessly strives.

But the poem refuses the simple surface meanings presented by the world it observes and records - "Too easy all this" (Sonnet 5, 105) - and seeks instead to reintegrate the initial theme of natural isolation into an elaboration of the observation of contemporary social decay and transience, metonymically indicated in "Broken windows" and "The police presence" (Sonnet 5,105 ). The sense of an ending is selfreflexively encoded in the contradictorily terminal enjambment of "End / of a line," and the central insight of the poem (and, by extension, of all Szirtes's poems about England) is asserted just before the central poem of the sonnet sequence:

This is your otherness where the exotic

Appears by a kind of homely conjuring trick. (Sonnet 5, 105)

These lines summarise the contradictory, complex concerns of this poem, and the thematic ambivalences that, Szirtes implies, connect his own experience to central elements of Sebald's writings. ${ }^{11}$ The "otherness" here is ambiguous, as "your" refers (as in Sonnet 2 and throughout Szirtes's work) to the narrator's self-address (and thus to his own sense of otherness from himself) as well as, implicitly, to the ad-

11. Sebald addresses the theme of exile most fully in The Emigrants, trans. Michael Hulse (London: The Harvill Press, 1996); see John Sears, "'Ghostly Presences' - Exile, Memory and Belonging in W. G. Sebald's The Emigrants," in Region - Nation - Belonging: Papers of the Literatures of Region and Nation Conference 2004, ed. David Roberts and Joss WestBurnham (London: Peter Lang, forthcoming). 
dressee of the poem - the reader - who may also be the poem's dedicatee, i.e. Sebald. The abrupt collocation in the same line of "otherness" and "the exotic" suggests the shared experience of Szirtes and Sebald as immigrant writers, resident within but not wholly belonging to the landscapes indicated in the poem; the appearance of these landscapes within the poem, metonymically summarised into condensed images, constitutes the "conjuring trick" of writing (the shared profession) which is "homely" precisely because it affords, within the familiar confines of language and literary traditions, accommodation for both Szirtes and Sebald.

This assertion of writing as affording symbolic accommodation (which, as we shall see, is later elaborated as the ideological assertion of "Meeting Austerlitz"), establishes the affinity of the word as the underlying territory of the poem; names, sagging vowels, the narrator's desire to "mouth the word that fits the case" and "History's human noises" (Sonnet 2, 103) retrospectively assume deeper significance in the light of the poem's central assertion. The "exotic," the outside of the familiar, located in significant end-focus, emphasises the embedded concern of the poem with the anomalous existence of the unfamiliar within the familiar, and expresses cogently the poem's sense of alienation from itself, its performance of the verbal "conjuring trick" that constructs the landscape it analyses as a space in which poetry itself is found. The poem itself becomes, in this reading, "exotic," an "outside" rendering of English mores and views, its careful aesthetic formalism rubbing against the crumbling, eroded formlessness of the natural and social worlds it observes, a delicate poetic construction superimposed upon the exposed flat territories of decaying East Anglia.

The second half of the poem initially develops this "exotic" dimension by focussing in Sonnet 6 on "A 1580s mural" (another figure of "the writing on the wall," signifying the impending ending that seems to preoccupy the whole sequence). Here Europe, in the form of "a trace of Rubens," and wider histories in "a touch, even, of Chinese / in the calligraphic lines," assert the discovered ancient hybridity of a landscape and a culture that has, until now, appeared symbolically but irreducibly English. New forms of expression are encountered in the old, "something far flung in the code / of a different language," but the significance is the same - the restoration of the mural is balanced by its depiction of "Devastation." As this modulates into the poem's extended critique of Conradian figures of empire ("New explorers come / out of the light to exploit the heart of darkness" [Sonnet 7, 106]), we return, as if on the homeward bound leg of a slow voyage, past the "biblical" "man with welded wings" (now more reminiscent of Icarus, and therefore of European rather than Biblical myth) in Sonnet 8, into a cinematic image of "The slow unravelling / of a long reel where everyone is travelling," an image that will return as the foundational metaphor 
of Szirtes's next collection, Reel. Return thus becomes unravelling, the homeward journey also a decline into old age (and home, implicitly, impending death and dissolution in "the sea" of Sonnet 11), as the next two sonnets summarise "The old in their gerontopolis" (Sonnet 10, 107) and "The dead fields in their last-gasp fantasy" (Sonnet 9,107$)$. The poem works towards its conclusion through an insistent invocation of the word "End!" (Sonnet 11, 108), a marking of England as the terminus of journeys (historical as well as geographical) from distant places that is also a question recognising the place shared by Szirtes and Sebald as one circumscribed, in the contemporary, by the possibility of the (British) empire writing back:

And what

are you doing here, yes, you and your friend

from Morocco, Uganda, St Kitts or Pakistan?

Whatever has brought you to this far, flat

kingdom with its glum farmers?

(Sonnet 11, 108)

The answer to the question asked of the "You" with its strange "friends" is provided at the end of this sonnet: "Homing. We are homing to the sea. Back / where we never were, at the end of the track" (Sonnet 11, 80), a return, the poem suggests, to non-existent, imagined origins implicitly located in history rather than geography. The concluding sonnet offers a lyrical summary of the persistent destructive forces of nature, of distance and proximity, of the confusion of sea and sky ("you could drown in sky / round here" [Sonnet 12, 8o] it asserts, suggesting an illusory death by water) characteristic of flat, featureless landscapes that connotes the non-difference of death. "Homing" is thus returning, a figure of the voyage towards death that ultimately grounds the allegory of "Backwaters: Norfolk Fields" on a complex concluding figure of historical closure.

Home, then, is a territory defamiliarised by historical processes that corrode the past and seem traceable only in the meticulous observation of the residues of the past surviving in the present, an illusory origin towards which the death drive, rendered as the force of historical movement, unconsciously pushes us. Szirtes's poem offers an extended meditation on the relations between migration, belonging and death within a specific, poetically rendered geography, and on the potential of language and of the literary text to afford a symbolic version of residency within this geography - a posthumous, post-historical literary existence in the comfort of writing - seemingly available to himself and, implicitly, to Sebald. If literature itself becomes, in this reading, a shared territory, criss-crossed by thematic repetitions and doubled concerns, then the asserted affinity between the two migrant writers serves 
to reinforce the potential of writing to respond to and, potentially, to alleviate, the experiential hostility of loneliness. These arguments are developed further, under radically different circumstances and under the impetus of a dramatically different emotional requirement, in "Meeting Austerlitz," a poem which of necessity assumes a significantly and pointedly more self-reflexive stance in relation to Szirtes's own poetic achievements.

\section{"Meeting Austerlitz"}

Utilising the form of the elegy to lament Sebald's death in 2001, Szirtes's long terza rima poem "Meeting Austerlitz" enacts a symbolically Dantesque encounter, a descent into the underworld of the poet's memory in order to perform a work of mourning. "Meeting Austerlitz" is a 243-line sequence of seven poems of irregular lengths, carrying the dedication "i. m. W. G. Sebald," that continues and develops Szirtes's exploration of long poetic forms and sequences. The terza rima form allows a schematic, structural continuity that extends the poem's concerns with the tension between coherence and rupture in experience, as well as extending its canonical range of reference to include Dante; as a response to the traumatic loss of sudden bereavement, the poem seeks a form to contain the effects of that loss, and finds it in Szirtes's characteristic reliance on reassuringly strict and aesthetically demanding formal structures, on formal experiment and on a typical rigidity of line and metre.

The focus of the poem's concerns extends, as I shall argue, from the specific circumstances of this particular memorial poem, the commemoration of an individual death, through words and themes explored in other poems in Szirtes's works, and into the English poetic tradition, even as it memorialises a writer and memories largely separate from or 'grafted onto' that tradition, and only tangentially connected to its own movement. Where "Backwaters: Norfolk Fields" contained its own rendering of (literary) history, displaced only momentarily into allusions to or echoes of Conrad and Sebald himself, in the later poem Szirtes asserts his own Hungarian origins and his own literary concerns as suitable analogies for the situation of Sebald's writing and his memory, which, like Szirtes's own writings and memories, now come into the possession of the writer. The poem becomes an elegy for both self and other, a simultaneous exploration of a literary friendship and a shared series of encounters with the weight of literary tradition that transcends each individual writer.

Formal characteristics and literary allusions take on particular significances as the poem constructs a space analogous to that familiar from "Backwaters: Norfolk Fields," a characteristic landscape and social context, in which the acts of writing and 
speaking enact forms of connection. The poem is, in consequence, a self-consciously literary work that mourns its own past as well as the personal pasts of which it writes, where the representational media of writing and photography have offered, as they do elsewhere in Szirtes's oeuvre (notably in The Photographer in Winter [1986] and in his 1994 collection Blind Field ${ }^{12}$ ) analogous and often complementary, if distinct, technologies of remembrance. In "Meeting Austerlitz" the individual death of Sebald offers a figurative space in which Szirtes's memories are reworked through the remembered mediation of the other writer; a double dialogue is established, between writer and writer and between poem and tradition.

Now collected in Szirtes's most recent volume Reel, for which he was awarded the 2004 T. S. Eliot prize for poetry, "Meeting Austerlitz" was first published in The Rialto $51 .{ }^{13}$ Its subsequent appearance, in 2004, as the opening text in a major volume of critical essays on Sebald's works ${ }^{14}$ raises questions about the place of poetry in critical discourse, and about what kind of discourse the poetic text might constitute when placed in a critical context. Effectively the poem is offered in this critical collection as a poetico-critical meditation on Sebald, a text to introduce and accompany the more formally literary-critical and theoretical essays which follow. The editors of $W$. G. Sebald: A Critical Companion offer the following introductory comment on "Meeting Austerlitz":

This volume begins, rather unconventionally, with a poem .... In the light of Sebald's untimely and shocking death, it offers a meditation on friendship, loss and memory. But it is also a lyrical engagement with Sebald's work; Szirtes takes up and develops the themes of walking and travel, employing similar techniques of allusion and quotation, and, like Sebald, embedding his philosophical speculations within a precisely delineated objectworld. 15

"Meeting Austerlitz" rests between this introductory chapter and the following critical discussions - it is, ultimately, neither introduction to nor commentary on Sebald's work, but instead both offers and occupies an in-between literary space in which that work is encountered by the work of another writer, in what appears initially as a poetic conversation. This space, analogous to the territory inhabited by

12. George Szirtes, The Photographer in Winter (London: Secker and Warburg 1986); Blind Field (Oxford: Oxford University Press, 1994).

13. Michael Mackmin (ed.), The Rialto 51 (Norwich: Rialto, 2002).

14. Long and Whitehead, W. G. Sebald: A Critical Companion, 16-22.

15. Long and Whitehead, p. 9. 
"Backwaters: Norfolk Fields," functions metonymically to signify the containment of the historical and its traces within geographical figures, and invites a comprehension of the poem itself as a similar space, a self-consciously formal structure that contains, in its allusions and formal borrowings, its own history.

Maurice Blanchot's extended theorisation of poetic space, in books like The Space of Literature and The Infinite Conversation, ${ }^{16}$ is useful in this context. Writing of Antonin Artaud, Blanchot describes "the idea of poetry understood as space,"

a space not of words but of the relations of words that ... is their moving suspension, the appearance of their disappearance; the idea of this space as pure becoming; the idea of image and of shadow, of the double and of an absence 'more real than presence'; that is, the experience of being as image before it is object, and the experience of an art that is gripped by the violent difference that is prior to all representation and all knowledge; the idea, finally, of art as revolt. . . ${ }^{17}$

These complex, contradictory characteristics of poetic space offer a series of figures that attempt to comprehend the poem as a form of representation in which absence is made present, in which the "violent difference" of words from things (specific to the literary text and its characteristic use of language) insists on the reality of the absence of things, and their absolute replacement by language, a "suspension" of meaning and signification from words themselves into the relations between them, culminating in poetry's ideational "revolt" against the loss of experience in history by performing in words its apparent return.

It is within this movement, this doubling, this being-as-image that the "inbetween" status or position of "Meeting Austerlitz" enables the poem to construct its exploration of death, memory and writing. The figure of Sebald is encountered in the form of a literary manifestation, his own fictional character Austerlitz, in which the apparent, spectral presence of the character allows the voice of the absent author to be heard after death; in this slippage between author and character the suspension of meaning occurs, allowing the poem to imagine its posthumous encounter as an exchange of words generating a textual event which affords the space for the analysis of that event and its possibility, but also establishing a degree of distance between the

16. Maurice Blanchot, The Space of Literature, trans. Ann Smock (Lincoln: University of Nebraska Press 1982); The Infinite Conversation, trans. Susan Hanson (Minneapolis: University of Minnesota Press 1993).

17. Blanchot, The Infinite Conversation, pp. 295-6. 
poem and its subject, who is encountered through an element of his own writing. The poem enacts memory as dialogue, a shared encounter extending beyond the personal experience of the poet into the literary tradition, and, in doing so, drawing that tradition, in true Modernist style, into contemporary speech.

"Meeting Austerlitz" opens with the solitude of the neutral observer which is also the solitude of writing, the alienation of the writer, commenting on but seemingly excluded from the social world he observes, working that social reality into a form in which his own solitude can be interrupted by the "Meeting" which gives the poem its title, and which takes place in Section 1 "some way off the road," "in the nearby fields" (17), a territorialisation which immediately links this poem's geographical symbolism with the "Norfolk Fields" of the earlier poem. This meeting-asinterruption opens up the poem's space of mourning, and leads to a series of remembered and imagined dramatic scenarios in which an extended conversation takes place between the two writers, where the voice of the dead writer, and the words of other texts he cites or alludes to, come to be heard within the written poem. These meetings and conversations construct, out of the poem's initial solitude, a writerly experience of imagined "being-together," a connectedness in which the specificity of the self is momentarily compromised in acknowledgement of the other, a moment in which one aspect of identity, "writer," with its sharing of literary traditions and forms, overrides other potential aspects of difference (nation, language, age).

This writerly "being-together" is a figure of mourning and desired connectivity with the dead which is theorised by Jacques Derrida in his obituary for Roland Barthes, ${ }^{18}$ where he argues that it expresses the writer's desire to engage the other in speech, to seek an influence, to ask for an opinion, an attitude, an idea. This desire underpins the imagined / remembered conversation in "Meeting Austerlitz," and imitates the conversational structure of Sebald's last novel Austerlitz, which narrates and enacts what it calls the desire of lone travellers "to be spoken to."19 It enables the figure of Austerlitz, a ghostly presence, a voice, a breath in the poem, to communicate within the literary space, to overcome the twin solitudes of writing and of death and exist alongside the 'neutral' voice of the poem, within a poem in which there can be a shared solitude, as Blanchot puts it, "a solitude in which they were no longer alone, ${ }^{20}$ resembling the time Derrida recalls spending "alone" with Barthes. ${ }^{21}$

18. Jacques Derrida, "The Deaths of Roland Barthes" in The Work Of Mourning, ed. PascaleAnne Brault \& Michael Naas (Chicago: University of Chicago Press, 2001), 31-68, pp. 55-7.

19. W. G. Sebald, Austerlitz, trans. Anthea Bell (Harmondsworth: Penguin, 2001) p. 14.

20. Maurice Blanchot, "Prophetic Speech" in The Book To Come, trans. Charlotte Mandel (Stanford: Stanford University Press, 2003), 79-85, p. 80. 
Aloneness or solitude is thus the paradoxical condition of being accompanied, in writing, by that which is absent, which allows in turn the possibility of colloquy within and across texts; it is the shared experience of the exotic (echoing the central theme of "Backwaters: Norfolk Fields"), modulated into the experience of exclusion and exile, experiences simultaneously unique and common to both writers. Their imagined "being-together" constructs a space outside of the social reality of the poem's opening section, a space "both day and night," as Austerlitz describes it in Section 1 (17), an imagined afterlife corresponding to the "night which is not night but the peaceful oneness of day and night" that Blanchot identifies in Novalis ${ }^{22}$ rather than the "other night" of "memory without rest" in which the absolute relation between literature's origin and death is, for Blanchot, made most inescapable. ${ }^{23}$ This safer double space, this "day and night" of "being-together," towards which Szirtes's poem tends and in which it seeks its hopeful resolution, is also the literary space in which the imagined colloquy with the dead can take place. It is a space of the familiar, only momentarily brushed by the space of the "other night" in which, Blanchot writes (alluding to Kafka), "the beast hears the other beast" 24 - or, in "Meeting Austerlitz," "Some creature squealed / in the distance. A car growled briefly past" (18). At this moment, "being-together" is momentarily threatened by the otherness of the outside, the experience figured in Sebald and in Szirtes as displacement, memory and homelessness - aspects of historical and geographical separation, of the singularities of "being-apart."

Sebald, an imagined figure renamed after his own compound fictional figure, Austerlitz, provides a voice in the poem offering a commentary on the circumstances of the two writers' meeting, on the poet's work (Szirtes's writing on wrestling), on history ("You can't explain / history to itself" [Section 4, 20]), and on names: "But names are like dreams we disappear into / where all things seem to fit into the frame / of their narrative. It is names we journey through. .." (Section 5, 21). These themes of writing, history and names constitute the literary territory explored by Szirtes's poem, a territory whose specific features and contours he shares with Sebald, and which have already been mapped out in different ways in "Backwaters: Norfolk Fields," in particular in that poem's assertion of names (in Sonnet 4) as traces of historical presence. Both are writers displaced out of country, even out of

\footnotetext{
21. Derrida, p. 55 .

22. Blanchot, The Space of Literature, p. 111.

23. Blanchot, The Space of Literature, pp. 163-4; see also "Sleep, Night," 264-8.

24. Blanchot, The Space of Literature, p. 168.
} 
language; both take the centrality of memory to the construction of imagined identities as a central concern, and both offer, in different ways, extended meditations on the experience of solitude that seems to characterise a particular configuration of recent European history and European literary modernity. Through Austerlitz's voice, we encounter parables of what the poem calls, in Section 2, "the homeless / intellect" (19), found here, in East Anglia, "a long way from his birthplace" (Section 3,19 ) on a "speculative journey / into melancholy" (Section 6, 23).

"Meeting Austerlitz" also locates itself within an English literary tradition of modern elegies, echoing in its title Wilfred Owen's "Strange Meeting" (1918)25 and alluding, in its opening lines, to the opening of W. H. Auden's "In Memory of W. B. Yeats" (1939), ${ }^{26}$ both poems by English writers addressing figures of other nationalities - the Irishman Yeats, and Owen's "one" who "sprang up," who, like Sebald, is German. ${ }^{27}$ A comparison between Szirtes's poem and these significant precursors enables the complexities of "Meeting Austerlitz" to become apparent, and establishes the extent of his poem's dialogue with its chosen tradition. Auden's poem famously opens "in the dead of winter: / The brooks were frozen, the air-ports almost deserted,"28 lines echoed in Szirtes's opening lines: "The cold sat down with frozen fingers. Cars / were iced up, the pavements were treacherous" (Section 1, 17); Auden's "Snow disfigured the public statues" 29 is revised and reversed by Szirtes's "Perhaps we were statues and time would pass / leaving us unaltered" (Section 4, 21).

In a more complex way, Auden provides a lexical and thematic link between Szirtes and Owen's famous assertion of "The pity of war, the pity war distilled" 30 in his lines "And the seas of pity lie / Locked and frozen in each eye,"31 which comment on human refusal and impotence in the face of the impending history which is the wider theme of his elegy for Yeats (and which retain a subtle ambiguity in the potential of "lie" to connote "untruthfulness" as well as reluctant or enforced passivity). The "freezing" of "pity" offers a condensed metaphor for the Modernist mood of frustrated empathy or paralysed suffering - for Auden, the impotence of poetry in the face

25. Wilfred Owen, The Poems of Wilfred Owen, ed. John Stallworthy (London: Chatto and Windus 1990), 125-7.

26. W. H. Auden, Selected Poems, ed. Edward Mendelson (London: Faber, 1973), 80-3.

27. Owen, p. 125. Stallworthy refers to Keats's “The Fall of Hyperion" as a source for Owen's description.

28. Auden, p. 80.

29. Auden, p. 80.

30. Owen, p. 127.

31. Auden, p. 81. 
of history - that characterises the tradition to which Szirtes's poem belongs. This line of descent connects his own poetry and the writings of Sebald to the melancholy characteristic of Modernist pessimism as experienced, in different ways, by Auden and Owen, in which frozenness usually connotes impotence and inability to act.

"Frozen" is a central word in Szirtes's poetic vocabulary. In the "Preface" to An English Apocalypse he writes about his early poems, some of which are collected in that volume:

Looking back it seems to me that my early poems, however stilted and occasionally frozen they appeared, were that way because they were in some sense the working through of dreams with real loved and vulnerable people at the core.

These dreamlike poems, frozen because they often dealt with frozen images from a frozen time, would seem no more than interesting examples of pathology, even to me, were it not that the world to which they provided an antithesis felt so dangerous and close. $3^{2}$

"The frozen dreams of pastoral," he continues, "appealed precisely because of their fragility." But the form of Romanticism inherent in this Keatsian "cold pastoral" is counterpointed, later, by Szirtes's professed admiration for Blake with his "burning energetic forms." 33 Frozenness is always, in Szirtes's poetry, arrested motion, the abrupt, often violent, curtailing of dynamism into stasis, something always potentially on the verge of heat and movement, the coldness of the past entering into the warm present. The "cold pastoral" of Keats's "Ode on a Grecian Urn" appears in an early poem, "The Silver Tree" (a poem from another long sequence called "Miserichords"), in an ekphrastic rendering that will become characteristic of Szirtes:

As the tree grows they grow, although

infinitely more slowly, and enter into

the frieze where mothers and smart daughters dance

in a cold pastoral. Ice is eating them. 34

Here the pun on 'freeze' again points towards arrested movement and its connection to aesthetic representation, and condenses the image in writing with the static, the immobile.

32. Szirtes, "Preface," p. 11.

33. Szirtes, "Preface," p. 12.

34. George Szirtes, November and May (London: Secker and Warburg 1981), p. 25. 
Szirtes's 1986 collection The Photographer in Winter offers some further examples of the importance of the frozen in his oeuvre. In "The Swimmers," the floor of Hitchin church is "like black ice" beneath which a river of "names, resemblances and epithets / Run by," a surface of deceptive stillness concealing the movement in depth that is the turmoil of hidden history. 35 In the long poem "The Photographer in Winter" we are offered another scenario with debts to Auden, a winter in Budapest in which "Bridges march across a frozen river" and "The elderly keep slipping into graves." 36 This poem is prefaced by an epigraph from Orwell's 1984: "He was hurrying along with frozen hands and watering eyes when he saw her not ten metres away from him. It struck him at once that she had changed in some ill-defined way." 37 Winston's "frozen hands" here balance Julia's "ill-defined" change, the static and the mobile in symbolic conflict, just as past and present (the fixity of one, the elusiveness of the other) balance writing and photography in Szirtes's poem. In the poem, "freezing" doubles as the photographer's instruction to a sitter: "Hold it right there. Freeze," 38 cementing the metaphorical potential of the word into its primary poetic function of signifying the static, the fixed element of memory as image, with which Szirtes's poetry is so powerfully concerned. Later the emotional force of the poem's elegiac agenda emerges in an image that returns us to Auden and Owen, condensing Owen's pity with the paralysed emotions of Auden and with the eye of Szirtes's photographer, a Modernist figure but not quite the disconnected "camera eye" of Dziga Vertov: "It can be dangerous to cry / When tears freeze on your cheeks"; this section concludes with, if not the "burning" of Blake, at least a thawing: "as I click the shutter / I feel the cold blood thawing in my veins." 39

In "Meeting Austerlitz" the frozen opposes remembered movement, so that the present is iced up and the past, in those moments where it intrudes into the present as memory, is movement, specifically the movement of Austerlitz's voice, defrosting the present: "Frozen motion. Blind field" states Austerlitz in Section 5 (21), quoting Szirtes quoting Barthes to himself. 40 This "frozen motion" is transformed, in the final

35. Szirtes, The Photographer in Winter, 11-14, p. 11.

36. Szirtes, The Photographer in Winter, 1-9, p. 2.

37. Szirtes, The Photographer in Winter, p. 1; see George Orwell, 1984 (Harmondsworth: Penguin 1974), p. 233.

38. Szirtes, The Photographer in Winter, p. 3.

39. Szirtes, The Photographer in Winter, p. 8.

40. George Szirtes, Blind Field, (Oxford: Oxford University Press 1994), p. 1; the phrase "Blind Field" is taken from Roland Barthes, Camera Lucida, trans. Richard Howard (London: Flamingo, 1984), 55-9. 
section, into erotic images of silky fluidity, momentarily overlapping in "Something silky froze / into permanence," but later, in the poem's concluding appeal to "hope," potentially more fluid, more mobile (Section 7,24 ). In contrast, the poem's opening offers a world of illusory stasis, of repetitive activity, the annual repetition of Christmas as consumer festival in which "The shops were a chorus / of seasonal favourites, every one the same," and the same shops all stock "the latest must-have toy / (each one expensive, every one alike)" (Section 1, 17). When the narrator meets Austerlitz, with his "droll / melancholy expression" (Section 1, 17), it is on a terrain in which "everything had a double or existed / in some version of itself wrapped in a winter cloak" (Section 1, 18). Against this backdrop of sameness and doubling which offers a series of figures for the banality of contemporary consumer reality, occurs the specific event of difference which defies belief, the death of Austerlitz: "I could not believe that Austerlitz was dead" (Section 2, 18). The stasis of death is thus, in an act of symbolic transference, translated into the repetition of existence; death becomes unique, an event outside of repetition, a frozen moment of specific inaction jarring with the debased, repetitive celebration of a birth that preoccupies the wider culture. Its unbelievable status is contrasted with other repetitive events, other deaths; Austerlitz is an other to the narrating self in this poem, but not, the poem argues, an "other" the same as the relentless sameness of "others": "Though others had died that year," the poem states, "his death was strange" (Section 2, 18).

It is the "strangeness" of this particular event, this specific death, which is the theme of Szirtes's meditation. Just as the meeting with Austerlitz is different, an encounter with an other rather than with the same, so his death marks this difference as significant, "strange" in the initial sense that combines "unfamiliar" and "foreign." The Shorter Oxford English Dictionary indicates the semantic richness and complexity of this word by listing ten distinct but overlapping meanings for "strange," the first of which is "Of or belonging to another country; foreign, alien." Others significant in this context include "Belonging to some other place or neighbourhood," "Belonging to others," "Added or introduced from outside," "Unknown, unfamiliar," and "Distant or cold in demeanour." Szirtes offers Sebald's death as multiply "strange" in its conflation of these different meanings, as being "other" than the "others" to which, in its strangeness, it would seem to belong. The death of the other is, like the other's existence in the shared historical and geographical spaces of "Backwaters: Norfolk Fields," an exotic event, introducing into "Meeting Austerlitz" the absent presence of the exotic other as dead, as "distant or cold" in its frozenness, its strange difference from the otherness of the alienating social reality of the poem. 
These meanings of the "distant," the "belonging to others," ultimately extend, of course, to account also for Sebald and Szirtes and the shared experience that they have carried into England as "strangers" themselves, writers living in England but nevertheless "Belonging to some other place or neighbourhood," "Added or introduced from outside" to the geo-historical matrix that constitutes England and its language and literature. Sebald's "strange" death thus affords space for a literary meditation on "strangeness" that takes up the multiple implications of "strange," established already in the poem's allusion to Owen's "Strange Meeting," itself an imagined encounter with the foreign and the dead - "Strange friend," 41 as Owen's narrator addresses his counterpart, oxymoronically confusing familiar and unfamiliar in precisely the way Szirtes's poem seems to address Sebald. In "In Memory of W. B. Yeats" Auden also uses the word "strange," with the sense of "Unknown, unfamiliar": "Time that with this strange excuse / Pardoned Kipling for his views."42 Strangeness is, of course, also the defining feature of the day of Yeats's death, and is present in synonymic form in Auden's poem: "a day when one did something slightly unusual," Auden writes, a day on which the dead poet becomes "wholly given over to unfamiliar affections." 43 In each poem, death is an event intrinsically connected with strangeness, with being or becoming estranged from the familiar, and with the distance pertinent to that which has become unfamiliar - to die is to become strange, to be estranged. At the same time, death, "Meeting Austerlitz" insists, is canonically and traditionally familiar, an event and theme repeated across the three poems, recurrent yet unique in its specificity, immediate to each poet as individual, unique experience, and at the same time a shift in reality that challenges "belief." Szirtes's meditation on Sebald's death explores these connections and contradictions through the juxtaposition of images of stasis with those of movement, the familiar with the unfamiliar, and ultimately in the opposition between loss and hope which, "Meeting Austerlitz" implies, characterises the poetic space in which such a "Meeting" can take place.

Contrasting its dominant mood of frozenness, Szirtes's poem offers movement in recurring clouds of breath, smoke and ash, signifiers of both life and death. Sebald's writing is remembered in these terms:

A puff of dust from the library, swirling like ashes, had settled across his prose, its flavour tart, magical and scholarly.

41. Owen, p. 125.

42. Auden, p. 81.

43. Auden, p. 81. 
Here, the collocation of "dust" and "ashes" implies burial and death even as its "swirling" re-establishes motion in writing, in the movement between "library" and "prose." If this is balanced by the stasis of "settled," the ambiguity of the word reintroduces migration and settling as embedded themes of Szirtes's meditation, opening again the space of writing as offering a potential accommodation to the migrant writer. Further echoes and allusions reinforce the literary tradition as homely territory. "We can distill / our terrors and make them hang like a grey mist / beyond the garden," Austerlitz notes in Section 3 (19), echoing Owen's "pity war distilled";44 at the end of Section 3, "He breathed out and the air stood still / before it vanished slowly like a ghost" (20). In the first section,

The air was frosty, oddly tobacco-scented, thick grey clouds rose from his mouth as he spoke.

I could not be certain whether the wisps that entered my mouth were frozen breath or cigarette smoke.

The strange figure of the transience of exterior intimacy offered by shared breath, "frozen" but balanced by the implicit heat of "cigarette smoke," momentarily connects the two writers, as does the expression of hope in poem's concluding section. "Whatever hope is yours," writes Owen in "Strange Meeting," "was my life also":45 "Meeting Austerlitz," following this declaration of shared aspiration, ends in "the Esperia Hotel in Athens" (23), returning to a similar mode of second person address through which we are informed of "The name / of the hotel, which, as you know, means hope" (24) The metaphor of the "Esperia Hotel" and, more pointedly, the extended ekphrastic description of the photograph of "the young girl in the garden" (24) that close Szirtes's elegy, establish literary dialogue between himself and Sebald as transcending death. The poem refers to a photograph from the drowned Welsh village of Llanwddyn of a girl with a doll and a dog, which is discussed and reprinted in Sebald's Austerlitz as one symbol (among many others in that narrative) of how lost things persist in images and writing, becoming, the narrator asserts, "as familiar to me as if I were living with them down at the bottom of the lake." 46

The closing assertion of "Meeting Austerlitz," then, is borrowed from Sebald and cements the dialogic relation between Szirtes's poem and the narrative from which Sebald's poetic persona is taken. This dialogic relation constitutes the shared experi-

44. Owen, p. 125.

45. Owen, p. 127.

46. Sebald, Austerlitz, pp. 73-4. 
ences of the strange becoming familiar and of identity within difference encountered by the two writers, establishing the shared, estranging but familiar territory of memory and its resurrections in various forms of representation as a common theme, as the literary space (a space already delineated and explored in "Backwaters: Norfolk Fields") within which each writer can potentially find a self. Szirtes's closing section makes use of poetry in ways analogous to the use Sebald's Austerlitz makes of photography, to 'unfreeze' the frozen or fixed memory and to explore its resonances in relation to experiences of exile and displacement. Where the earlier poem establishes English spaces and histories as territories of contradictory, shared experiences of inclusion and exclusion, the later one shifts its focus onto the elements of English poetic tradition in order to seek out a space within which Szirtes can poetically express these experiences.

"Backwaters: Norfolk Fields" and "Meeting Austerlitz" constitute major poems in George Szirtes's oeuvre, offering long, complex poetic meditations on the connections between and shared concerns of his own writings and those of Sebald. Both poems work to reconcile the themes of memory and hope, word and image, living and dying within the space of literature, offering, in the final lines of "Meeting Austerlitz," the metaphorical hotel of hope as a temporary accommodation for the estranged, migrant writer, a momentary residing in a strange, foreign tongue and in its literary traditions, a figure for the accommodation Szirtes and Sebald have shared in England and in English, and also in writing. 